\title{
Determination of School Leaders' Values, Their Levels of Practice and Differences
}

\author{
Jeffri Idris \\ Institut Aminuddin Baki, Malaysia
}

\begin{abstract}
.
This study sought to get a better understanding on the extent of values being considered and practised by the school heads. This is important because school heads, as well as teachers are considered role models by their students and community, therefore these school heads should 'lead by example'. The objectives of the study were to determine their most favoured values, their levels of practice and their differences. A quantitative approach was used by employing a survey instrument to gather the data. The values assessed were categorized into four domains, namely Basic Values, Professional Values, Morale Values and, Social and Political Values. There were 105 school heads from most parts of the country purposely selected for the study. The respondents were from both primary and secondary schools and comprised both gender. The respondents were required to self assessed their values practice using the five-point Likert Scale items. It was decided that 94 survey questionnaire forms to be selected and analysed. Based on the item analysis, it was concluded that the respondents scored considerably high in all the four domains. It was also discovered that there were no significant differences in the practice of values between primary and secondary school heads, gender and geographical locations. There was also no significant difference in terms of years of experience as school heads. Although their levels of values practice were mostly high, suggestions were made to further strengthened their values-based leadership particularly the Moral Values domain.. It was also suggested that a 360 degree type of assessment to be used in future study to get different perspectives to support the findings of this study. Lastly, this study has contributed to the body of knowledge in terms of values-based leadership among the school heads in the country.
\end{abstract}

Keywords: Leadership, School leaders, Values

\section{Introduction}

Leadership values play an important role in determining the survival of an organization. Studies have proven that the fall of many big organizations could be linked to their failure in prioritizing and emphasizing values in their business practise. Instilling values in every aspect of organizational practices should be considered as part of their strategic planning practice. More importantly, values need to be considered in every decision making process.

Theoretically, there are values-based leadership (VBL) practices in existence. Some of these are Servant Leadership, Authentic Transformational Leadership, Spiritual Leadership and Ethical Leadership (Copeland, 2014). Leadership values proposed by Leithwood, Day, 
Sammons, Harris dan Hopkins (2006) can be viewed as relevant in educational leadership context.

Educational leaders should be in the forefront of championing values-based leadership. They are not only required to practise it but to ensure that future generations are equpped with all the values to be good citizens. This is especially true to school leaders who are dealing with people of the future generations.

It was hoped that this study could provide a new perspective on the practice of VBL among the school leaders. This study would reveal how important the values were for the school leaders in carrying out their duties as administrators.

\subsection{Background}

Principals or Headmasters are instructional leaders at school. Their main responsibility is to ensure student achievement through the effectiveness of teaching and learning activities. There are three main functions to be implemented as instructional leaders namely defining school mission, managing instructional programmes and promoting school climate according to Hallinger (2018).

It is important that values to be practised by the school leaders in executing all the three main functions. This is based on the findings that effective leaders and organizations possesed strong moral and ethical principles (Copeland, 2014). Therefore, it is relevant to know the extent of values consideration among the school leaders in the country when implementing their roles and responsibilities as instructional leaders. This could help related stakeholders to think and plan steps to strenghten the practice of VBL.

\subsection{Problem Statement}

As school leaders, Principals and Headmasters are role models to students as well as teachers. They should lead by example in a sense that they practice and show the principles of moral and ethics throughout the process of managing and leading the school. It is therefore relevant to know how do these school leaders regard the importance of values in carrying out their jobs and responsibilities. This is because empirical evidences on measuring the extent of values being practised by the school heads in the country are not widely available. Perhaps there are not many studies focusing on this matter. Without having a clear understanding on the levels of values practices would make it difficult for concerned stakeholders. For example, there could be a problem in efforts to strengthen the practise of good values in terms of providing training, policy making, etc.

School leaders who do not see the importance of values would eventually become ineffective and lose respect from their staff. As a result, teachers could be de-motivated that would later affect the students and school. This is because leaders who practise VBL are highly trusted that they are able to create competent, efficient workers with leadership skills (Leithwood, et al., 2006; Dean, 2008; Viinamaki, 2009; Taylor, 2011 \& Copeland, 2014). 


\subsection{Objectives of the Study}

The study was carried out based on the following objectives:
i. To identify the important values as regarded by the school leaders.
ii. To determine the levels of values-based leadership practised by the school leaders.
iii. To determine the relationships between the values-based leadership and demographic attributes.

\subsection{Literature Review}

Values simply refer to what is good, right, and appropriate (Peregrym \& Wollf, 2013). According to Striepe, Clarke, and O'Donoghue (2014), values are based on one's beliefs and guide their practice of leadership. Peregrym and Wollf (2013) explain that in addition to belief, one's values are influenced by family, community, education, current life and work experience. According to Barrett (2014), a person's concept of value is not constant because it can change according to the individual's current needs. In essence, according to Barrett, one's own values depend on what is considered important and what is needed at that time. For example, at a young age the value of friendship is one of the most important but as one's age increases, the value of integrity becomes more important.

VBL refers to leaders who hold to their values by doing the right things for the right reasons and aligning them with organizational values (Dean, 2008 \& Copeland, 2014). In this context, the leadership style of a Principal or Headmaster does not influence the values they hold but will reinforce them (Niekerk \& Botha, 2017). Viinamaki (2012) explains that factors that influence one's values are individual, current state, organization, education and gender. In addition, Mohamad Khairi and Asmawati (2010) state that school type, school environment, school culture, teacher experience and teacher personality can influence the application of values among students.

The concept of VBL is based on the philosophy of who we are and how we act, not the position we hold (Taylor, 2011). According to Viinamaki (2009), VBL acts as a complement to existing leadership initiatives, rather than as an alternative approach. VBL's conceptual framework is related to the theories of Servant Leadership, Authentic Transformation Leadership, Authentic Leadership and Ethical Leadership (Copeland, 2014).

VBL is important to practice and should be the core of an organization's management. Tom Peters, an author and expert in the field of self-management emphasizes that a leader's key role is in managing organizational values (Peters \& Waterman, 2006). Steve Jobs, founder of Apple Computer has also stated the importance of management through values to ensure organizational success (Dean, 2008).

There are many sources of literature that discuss why VBL should be practiced. Among them are Leithwood, et al. (2006), Dean (2008), Viinamaki (2009), Taylor (2011) and Copeland (2014). Among its importances are:

1. An action is actually influenced by the values it holds, so leaders need to know and understand clearly what values they hold.

2. An action taken by a leader will affect the values of the organization, so the leader must determine what values need to be instilled in the organization. 


\section{ARERL}

\section{$3^{\text {rd }}$ International conference on Advanced Research in Education, Teaching \& Learning}

3. Leaders who adopt the VBL can produce successful organizations through highly skilled, competent and capable staff.

4. Leaders who practice VBL can build the trust of their subordinates and their customers.

5. Decisions or actions based on values are the best method, especially in complex and uncertain situations.

In addition, studies have also shown that there is a link between the excellent school leaders and VBL practices. Among the findings of the study were outstanding school leaders had high regard and concern for others including happiness for ownselves and others. They also had a high degree of integrity and morality (Leithwood, Day, Sammons, Harris \& Hopkins, 2006).

Abbasi, Rehman and Bibi (2008) list eight key values in Islam that are required for leadership. These values are sincere, perfect (compassionate), just, true, patience, continuous reflection, fulfilling and simple. Peregrym and Wollf (2013) suggest five key values for leaders: integrity, curiosity, compassion, humility and confidence. Leithwood, et al. (2006) further divided the values of leadership into four categories namely basic human values, general moral values, professional values and social and political values.

INTAN (1991) has listed the values that public servants should hold. These values were divided into five main categories namely basic personal values, customer preference values, leadership values, professional values and productivity/quality values.

\section{Methods}

This study used a quantitative approach where the data were derived from questionnaire forms distributed to identified samples. It involved 94 respondents that comprised school leaders. They were all Principals and Headmasters selected based on purposive sampling method.

This study used questionnaire form as the instrument designed based on the research questions identified. The constructs and items in the questionnaire were based on existing assessment tools and modifications. The instrument was tested and piloted prior to administering it to the targeted samples.

\section{Results}

A total of 105 questionnaires were received out of 150 distributed forms. After screening and selecting, only 94 questionnaire forms were analyzed. Cronbach's Alpha reliability test for all items in the questionnaire showed a high reliability of 0.97 .

Demographically, it was discovered 66 percent were male respondents and 34 percent female respondents. There were 57 percent of them from the urban schools category and 39 percent from the rural schools. 
Table 1: Values-Based Leadership Analysis Based on Constructs

\begin{tabular}{lccc}
\hline Constructs & No. of Items & Mean & SD \\
\hline Basic Values & 9 & 4.44 & 0.634 \\
Professional Values & 33 & 4.46 & 0.592 \\
Moral Values & 21 & 4.32 & 0.644 \\
Social dan Political Values & 21 & 4.40 & 0.604 \\
Overall & 84 & 4.41 & 0.310 \\
\hline
\end{tabular}

Table 1 shows the mean analysis of the questionnaire items based on the four key constructs of leadership values. For the Basic Values practice containing nine items, the mean obtained was $4.44(\mathrm{SD}=0.634)$. This analysis shows that respondents consistently practice leadership values related to these Basic Values.

The practice of Professional Values comprised 33 items in the questionnaire also indicated that respondents practiced them highly (mean $=4.46, \mathrm{SD}=0.592$ ). Also, respondents acknowledged that they always practiced values related to Moral Values (21 items) (mean = 4.32, SD = 0.644). For the Social and Political Values (21 items), the analysis also found that respondents used it consistently (mean $=4.40, \mathrm{SD}=0.604$ ).

Based on the overall analysis of the $84 \mathrm{VBL}$ practice items, the study found the mean was 4.41 ( $\mathrm{SD}=0.310)$. In conclusion, the analysis of values-based leadership practices among the respondents were practiced highly. Based on the mean, the Professional Values was the highest (4.46) and the lowest was Moral Values (4.32).

Inferential analyses were also carried for the study based on hypotheses formulated. Firstly, the study found no significant differences of VBL practices between primary and secondary school leaders. Secondly, there were no significant relationships of VBL practices in regards to years of experience. Thirdly, there were also no significant differences of VBL practices between school leaders in urban and rural areas. Lastly, there were no significant differences of VBL practices between male and female school leaders.

\section{Discussion}

This study was carried out based on the importance of the role of values in ensuring the success and sustainability of an organization. In this context, leaders have a great influence on determining the values that should be practiced in their organizations and shared by all members of the organizations. These values are often influenced by the individuals who lead the organization.

The findings of this study as a whole illustrated that the respondents who were school leaders had an awareness of the importance of practicing good values in carrying out their duties and responsibilities as administrators in their schools. This was based on the analysis of the study which found that their VBL practices as a whole yields a mean of 4.41 and for the four dimensional values, the means were between 4.40 and 4.46. All of these showed that values were considered in their management and leadership practices. 
Additionally, inference analysis was conducted to identify the relationship between school category, experience, school location and gender as independent variables and the practice of VBL as dependent variable. The results of the analysis found that there were no significant differences or relationship existed between the demographic attributes and the practice of VBL. These indicated that the practice of VBL among the school leaders was not related to the different types of demographic background.

\section{Conclusion}

This study involved only a group of Principals adn Headmasters serving under the Ministry of Education Malaysia. These include the various types of secondary and primary schools according to the categories set by the MOE. The findings of this study were based on the data collected using the survey questionnaire developed based on the purpose, objectives, research questions and hypotheses of the study. In addition, the data analyzed were based on the selfassessment of the respondents, which may have a tendency to rate their own value practices higher than if they were rated by a third party. The findings of this study did not necessarily reflect the overall school leaders because of the small number of respondents and sample selection was not randomized.

Therefore, the study has identified suggestions that can be considered:

1. Identify and set core values that are agreed upon and share them with all the school staff and students.

2. Re-align the mission and vision of the school to take into account aspects of values identified in each planning and implementation of activity.

3. Create a positive school climate and culture based on shared values.

4. Implement value-based decision-making practices instead of data-based. .

\section{References}

Abbasi, A. S., Rehman, K. U., \& Bibi, A. (2010). Islamic management model. African Journal of Business Management, 4,18, 4003-4020.

Barrett, R. (2014). The values-driven organization: Unleashing human potential for performance and profit. London: Routledge.

Copeland, M. K. (2014). The emerging significance of values based leadership: A literature review. International Journal of Leadership Studies, 8,2, 105-135.

Dean, K. W. (2008). Values-based leadership: How our personal values impact the workplace. The Journal of Values-Based Leadership, 1, Iss. 1, Article 9. Available at http://scholar.valpo.edu/jvbl/vol1/iss 1/9

Hallinger, P. (2018). Principal Instructional Leadership. In The Wiley Handbook of Teaching and Learning (eds G.E. Hall, L.F. Quinn and D.M. Gollnick). doi:10.1002/9781118955901.ch21

INTAN. (1991). Nilai dan etika dalam perkhidmatan awam. Kuala Lumpur: Institut Tadbiran Awam Negara. 


\section{ARERL}

\section{$3^{\text {rd }}$ International conference on Advanced Research in Education, Teaching \& Learning}

Kementerian Pendidikan Malaysia. (2013). Pelan pembangunan pendidikan Malaysia 20132015. Putrajaya: Kementerian Pendidikan Malaysia.

Leithwood, K., Day, C., Sammons, P., Harris, A \& Hopkins, D. (2006). Successful school leadership what it is and how it influences pupil learning. Nottingham, UK: National College for School Leadership and Department for Education and Skills.

Mohamad Khairi Othman \& Asmawati Suhid (2010). Peranan sekolah dan guru dalam pembangunan nilai pelajar menerusi penerapan nilai murni: Satu sorotan. MALIM SEA Journal of General Studies, 11, 117-130.

Peregrym, D. \& Wollf, R. (2013). Values-based leadership: The foundation of transformational servant leadership. The Journal of Values-Based Leadership, 6, 2, Article 7. Available at http://scholar.valpo.edu/jvbl/vol6/iss2/7.

Peters, T. J. \& Waterman, R. H. (2006). In search of excellence: lessons from America's bestrun companies New York: HarperBusiness Essentials.

Striepe, M., Clarke, S., O'Donoghue, T. (2014). Spirituality, values and the school's ethos: factors shaping leadership in a faith-based school, Issues In Educational Research, 24, $1,85-97$.

Taylor, D. H. (2011). The power of values-based leadership. Available at http://www.davishtaylor.com/documents/ThePowerofValuesBasedLeadershipSample.pdf

van Niekerk, M. \& Johan Botha, J. (2017). Value-based leadership approach: A way for principals to revive the value of values in schools. Educational Research And Reviews, $12,3,133-142$.

Viinamäki, O-P. (2009). Intra-organizational challenges of values-based leadership. Electronic Journal of Business Ethics and Organizational Studies, 14, 6-13.

Viinamäki, O-P. (2012). Why Leaders Fail in Introducing Values-Based Leadership? An Elaboration of Feasible Steps, Challenges, and Suggestions for Practitioners. International Journal of Business and Management. 7, 10, 28-39. 